\title{
Invasive Pest and Disease Pathogen as Sneakers in Railways for Their Spread in Different Ecological Region: A New Report
}

\author{
S. G. Borkar
}

\section{ABSTRACT}

A new pathway of travels by invasive pest and disease pathogen through railways, as sneakers, were noticed for the first time. The Indian railways passing through the soybean fields infested with Spodoptera litura, after evening attracted the moth of Spodoptera by the illuminating lights in the railways compartment and the moth enters into the compartment through open compartment windows. These moths remain in the railway compartment until the dawn and get out of the compartment as the early morning sun light enters into the compartments and are thus the sneakers crop pest in railways due to their unnoticed travels/transport. Such sneakers crop pest travels up to a distance of $600 \mathrm{~km}$ during the period of night from one ecological region to another ecological region having the same crop to infest or the alternative host crop of the pest to cause the fresh infestation. This phenomenon of pest travel was observed in the region of Lalitpur in Uttar Pradesh, India, having soybean infestation. This is a quick travel by the pest into different areas, unseen and unreported earlier and may occur in any part of the world where the railways pass through the infested crop areas and attract the positive phototaxis pest and transport them, as sneakers, in to another ecological region.

In another instance, the Sigatoka disease pathogen of banana was also noticed to travels from one ecological region to another ecological region through the railways, as sneakers without notice. This phenomenon of disease pathogen's travels was noticed in Jalgaon region from where the banana produce is transported to different parts of India. In the trading and transport of banana through railways, the loaders use the banana leaves infected with the sigatoka pathogen as a packaging material for banana bunches while loading the banana produce in the railway wagons for their transportation. Thus, the sigatoka pathogen travels up to a distance of $1200 \mathrm{~km} /$ day along with the banana produce through the railways. The sigatoka infected leaves, with the unloading of banana produce also sneaks into the new ecological region and spread to infect the banana crop available in the region.

Thus, the positive phototaxis insect pest are the sneakers in the railways for their travels while diseases pathogens with healthy crop produce travels and embarks to sneaks into a new ecological region and thus the railways transport system unintentionally transport the crop pest and disease pathogen from one ecological region to another. The knowledge of this new travel pathway will be useful in finalizing the strategies of plant quarantine and management of invasive pest and disease pathogens.

Keywords: Invasive Crop pest, Illuminating light attractant, Sneakers, Travel, Railways, Invasive Disease pathogen, ecological region.
Submitted : February 2, 2021

Published : February 19, 2021

ISSN: $2684-1827$

DOI: $10.24018 /$ ejfood.2021.3.1.238

S. G. Borkar

Dr. Borkar's Soil, Seed, Plant Disease

Diagnostic and Research Center, India

(e-mail: borkarsg@yahoo.co.in)

\section{INTRODUCTION}

Invasive pests and disease pathogens cause huge losses to the agricultural crops world over. In USA alone, the losses are reported to the tune of 137 billion US dollars per year [1], [2]. The pathways responsible in the travels/transportation of these pests and diseases pathogen from one ecological region to another, plays the most important role in the arrival and establishment of the pest and disease in the new area. Generally, the pest and disease pathogens are carried through the infested (in case of pests) or infected (in case of diseases) seed/planting material/food grains/fruits and vegetables. Where the plant quarantine systems are in operation particularly at airport/seaport/land borders, the arrival of plant material are inspected for the invasive /invasive alien pests; however, within the inland the system of plant quarantine does not operate to the desirable extend. These pave a way for the travels and dissemination of the pest and disease pathogen to another areas/ecological 
region within the country. Travels by phototaxis pests, as sneakers, and disease pathogen by railways is a new pathways of pest transport which are described in this study.

\section{CASE STUdy 1}

Travels of Invasive crop pest Spodoptera litura, as sneakers, through railways:

\section{A. Spodoptera litura as Invasive Crop Pest}

Spodoptera litura, is one of the most important insect pests of agricultural crops in the Asian tropics. It is widely distributed throughout tropical and temperate Asia, Australasia, and the Pacific Islands [3], [4]. The pest is polyphagous [5] and therefore have huge potential to invade new areas and/or to adopt to new climate and/or ecological situation. The host range of S. litura covers at least 120 species of plants, the important one is cotton, flax, groundnut, jute, lucern, maize, rice, soybeans, tea, tobacco, vegetables, okra, cabbage, cauliflower, ornamentals, shade trees, teak etc.

Spodoptera litura larvae are polyphagous defoliator, seasonally common in annual and perennial agricultural systems in tropical and temperate Asia. This noctuid is often found as a part of a complex of lepidopteran and nonlepidopteran foliar feeder. Hosts include field crops grown for food and fibre, plantation, and forestry crops, as well as certain weed species. It is reported to cause $12-23 \%$ damage in tomatoes in monsoon season while $9-24 \%$ damage in the winter [6]. The damage in potato crop ranges from 20 to $100 \%$ in different parts of the fields depending on the moisture availability [7]. It causes extensive defoliation of soybean [8] as severe as $48.7 \%$ during the pre-bloom stage of growth. Several infestations led to skeletonization of leaves. Japanese soybean field plots artificially infested with one or two $S$. litura egg masses per plant suffered estimated leaf area reduction of 14.3 and $23.2 \%$ and yield losses of 13.9 and $24.7 \%$ respectively [9]. In eastern Asia, damage by $S$. litura occurs as far north as Japan, extending south to Indonesia. S. litura causes damage to many species of forest and plantation trees and shrubs [10]. In teak, it is one of about 139 defoliators that attack all stages from seedling to mature trees. S. litura is abundant on teak in June and July and damage incidence in seedling has been reported to be as high as $56 \%$. Late instar larvae were found to feed preferentially on mature teak leaves, whilst early instars fed on leaves of intermediate age [10].

\section{B. Pest Life Cycle}

The newly hatched larvae can be detected by the scratch marks they make on the leaf surface. The older larvae are night feeders and are usually found in the soil around the base of the plant during the daytime. They can chew large areas of leaf and at high population densities cause complete defoliation. The larvae can migrate in large groups from one field to another. The larvae go through six instars. Individual larvae can consume around $4 \mathrm{~g}$ fresh weight of groundnut foliage. However, $80 \%$ of the total consumption is in the final instar.

After adult emergence, peak oviposition occurs on the second night. Females mate three to four times during their lifetime, while males mate up to 10 times. In Andhra Pradesh, India, S.litura completes 12 generations a year, each lasting slightly more than a month in winter and less than a month in the hot season.

\section{Means of Movement and Dispersal}

\section{Natural dispersal}

The moths have a flight range of $1.5 \mathrm{~km}$ during a period of $4 \mathrm{~h}$ overnight, facilitating dispersion and oviposition on different hosts [11]. They can accordingly fly quite long distances. The caterpillars can migrate over short distances.

\section{Accidental introduction}

In international trade, eggs or larvae may be present on planting material, cut flowers or vegetables. The pupae can be present in soil. The pupae are long lived and could be transported over a considerable distance if not crushed, but to establish a viable population several specimens of both sexes need to be transported.

\begin{tabular}{ccc} 
3. & Transport Pathways & \\
\hline Sr. No & Transport pathway & $\begin{array}{c}\text { Insect stages likely to be } \\
\text { transported }\end{array}$ \\
\hline 1. & Aircraft & Eggs, Larvae, pupae \\
2. & Land vehical & Eggs, Larvae, pupae, moth \\
3. & Wind & Adult moth \\
\hline
\end{tabular}

\section{New Transport Pathway, as sneakers, through} railways

It is well known that insects fly towards streetlamps or other outdoor illumination at night due to their innate phototactic behaviour [12] and this helped them for their movement at night periods. The Indian railways passing through the soybean fields infested with $S$. litura, at the evening time after sunset, attract the moth of Spodoptera by the lights in the railways compartment and the pest moth enters the railways compartments through open compartment windows (Fig 1).
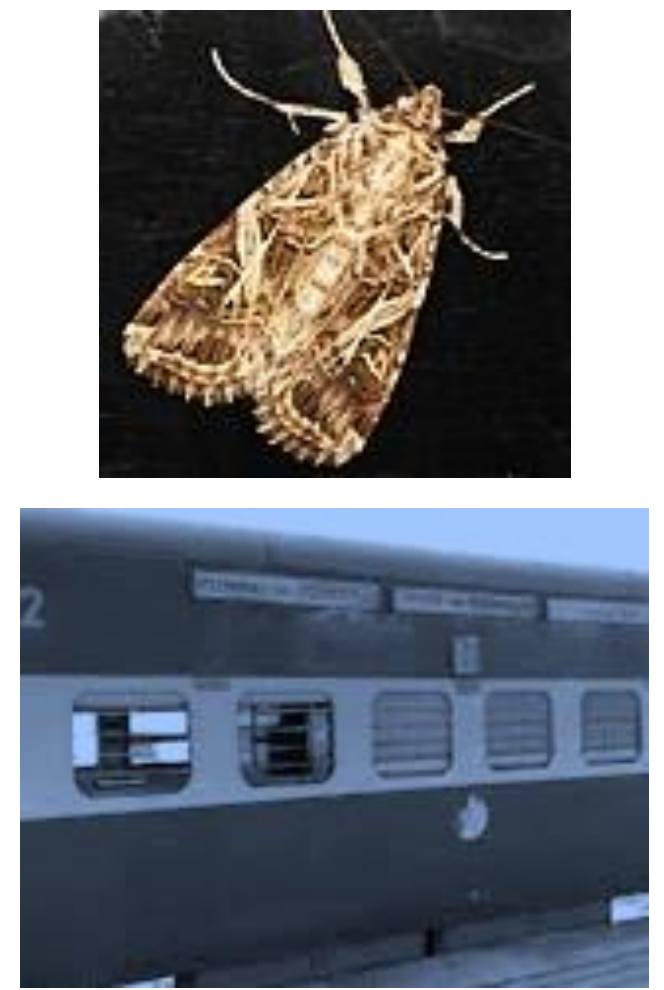

Fig. Adult moth of S.litura attracted towards railway compartment lights and sneaking in railway compartment through open windows. 
These moths remain in the railway compartment until the dawn and get out of the compartment at the early morning as the sun light enters in the compartments and are thus the sneakers crop pest in railways which travels without the notice of personnel concerned with plant protection system/railway authorities. Such sneakers crop pest travels up to a distance of $600 \mathrm{~km}$ during the period of a night from one ecological region to another ecological region having the same crop or the alternative host crop of the pest to cause the fresh infestation. This phenomenon of new transport pathway for this pest was observed in the region of Lalitpur in Uttar Pradesh, India having soybean infestation, by passenger railways passing in the region just after the sunset and the pest moth get out of the railway compartment at the time of early morning sun rise. Such pest arrival into new ecological region exposes the host crops of the pest for the newly arrived pest invasion and damages. This is a quick travel by the pest into different areas, by the railways, unseen and unreported earlier and may occur in any part of the world where the same situation is available.

\section{CASE STUDY 2}

\section{Unintentional transport of Sigatoka disease pathogen of banana through railways:}

\section{A. Sigatoka as Important Disease}

Sigatoka of banana caused by fungal pathogen Mycosphaerella musicola and Mycosphaerella fijiensis var.difformis is an important disease prevailing in around 96 countries of different continents comprising of 25 in Africa, 16 in Asia, 27 in North America, 18 in Oceania and 10 in South America [13]. Its name comes from the Sigatoka Valley in Fiji where it was first identified in 1912. Without control measures, black sigatoka can reduce bunch weight by up to $50 \%$ and cause a $100 \%$ loss of production due to a reduction in quality. The eradication cost of early detected sigatoka leaf blight disease in Tully area of Queensland in Australia is reported to the tune of 17 million Australian dollars in 2009 [14]. In India, Jalgaon district of Maharashtra state is known as a motherland of banana cultivation with an acreage of 48,000 hector having annual production of 3.4 million metric tonnes [15]. The banana crop in the district is mainly suffered by sigatoka leaf blight disease (Fig. 2) and prevails around the years due to availability of different stages of crop growth in the banana fields.

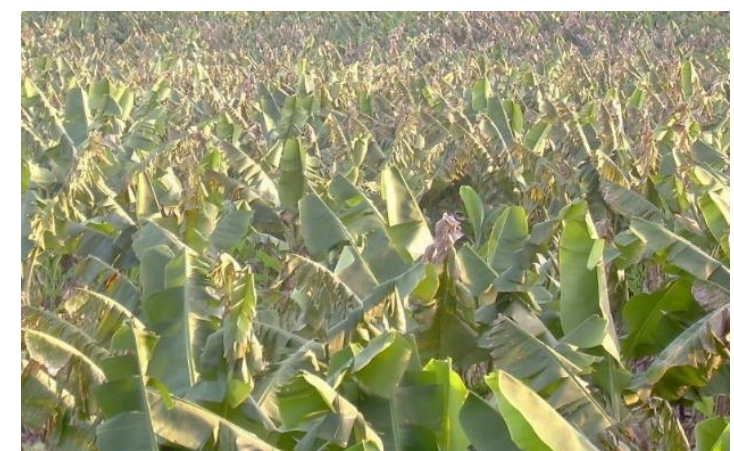

Fig. 2. Infection of Sigatoka disease in Banana field in jalgaon region.

\section{B. Sigatoka Pathogen and its Perpetuation}

The sigatoka pathogen Mycosphaerella musicola and Mycosphaerella fijiensis var.difformis perpetuates in the disease leaves, disease leftover thrown on the farm side after banana harvesting, in banana plantation soils and infects the new plantings. The most favourable atmospheric conditions for the perpetuation and spread of the disease are 25 to $28{ }^{\circ} \mathrm{C}$ temp with 80 to $90 \%$ relative humidity [16]. Wind currents play an important role in the spread of fungal inoculum whereas latent infection carried by tissue culture planting material spread the disease as a long distance spread.

Unintentional long distance spread of the disease pathogen by railways through banana trading was not yet known which is reported in the present case study.

\section{Transport of banana and Sigatoka through Railways Wagons}

Long distance transport of banana from Jalgaon district to other parts of the country viz. Delhi, UP, Uttarakhand, Jammu and Kashmir, Bihar, Assam, West Bengal, Odisha, North-East states by Railways wagons is a regular feature at the railway stations of Jalgaon distracts. The banana harvest is brought to the railway stations along with the sigatoka infected leaves (Fig. 3) to prevent it from direct sun and also as a packing material to avoid the brushes during the transport. These banana bunches are loaded in the railway wagon with the sigatoka infected leaves (Fig. 4) as a packing material along- side of the wagon compartment to avoid the brushes during train transportation for a long distance.
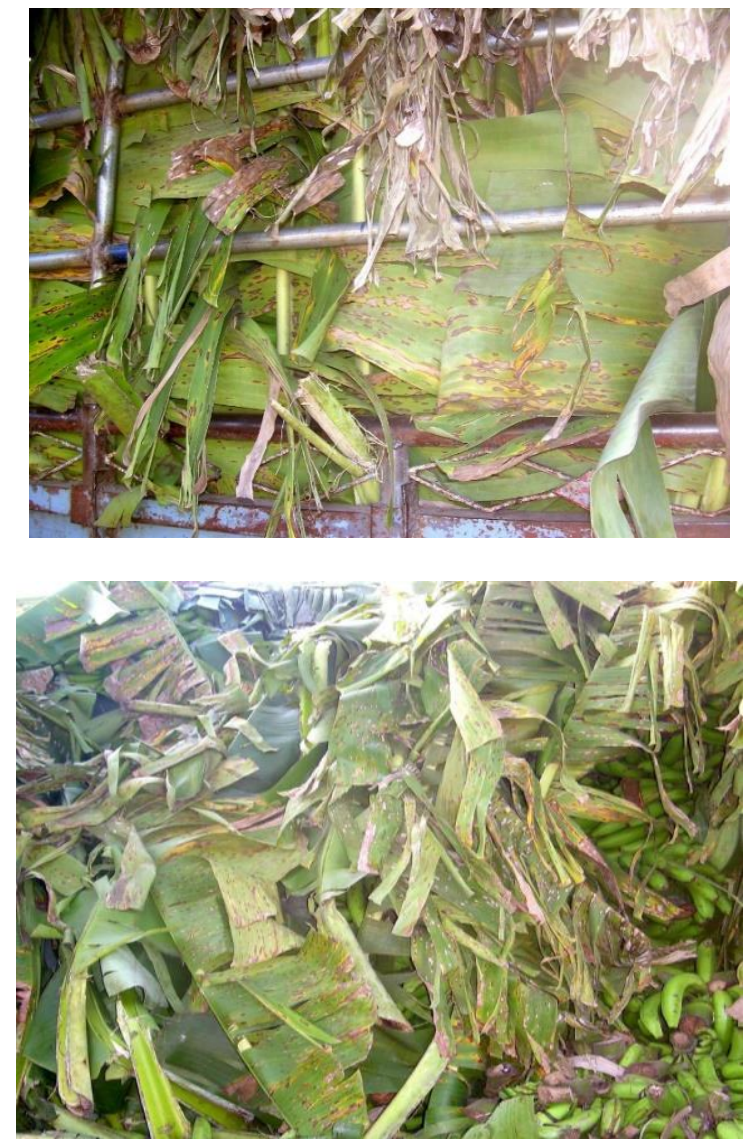

Fig. 3. Transportation of banana produce from farm to railways in tractor trolleys in sigatoka infected leaves cover. 

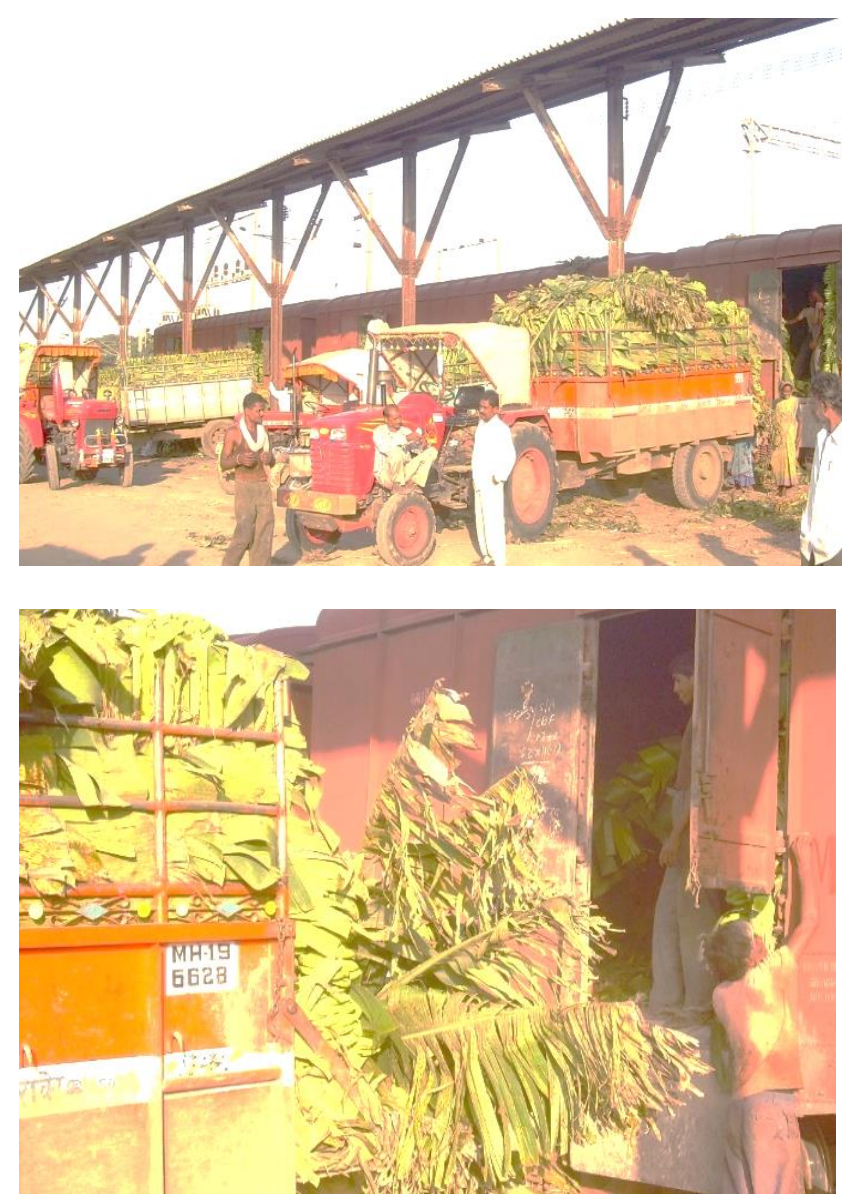

Fig. 4. Loading of banana in railway wagon with sigatoka infected leaves.

Thus, the sigatoka pathogen travels a long distance through infected diseases leaves by railways. When these banana produces are disembark at different locations in other states, along with its infected diseased packing material, the pathogen find new ecological region for its survival and infection if the banana crop is present in that area. This is the unintentional and unreported mode of travel by a plant pathogen in new ecological region.

Although national plant quarantine system is in operation for restriction of entry of invasive pest and diseases from foreign countries; the inland plant quarantine system is seldomly operative. There are no plant quarantine personnel available at railway stations as observed at airport or seaport. The absence of quarantine people at such places facilitates the movement and transport of invasive pest and diseases within inland ecosystems. Though, the transport of the pest and disease through railways is unintentional, it cost to the agriculture production in term of losses, and the pest management expenditure.

\section{CONCLUSION AND RECOMMENDATION}

There is a need to make aware the cultivators and railways personnel on the issue of invasive pest and diseases which are likely to be transported to other ecological regions through railways and pose threat in the new area to the agriculture and crops. This will also help to regulate the system of inland plant quarantine to restrict the movement of invasive pest and diseases within the country.

\section{REFERENCES}

[1] Pimentel, D., L. Lach., R. Zuniga and D. Morrison. 2000. Environmental and economic costs of non-indigenous species in the United States. BioScience. 50: 53-65.

[2] Nifa,2020. Invasive pest and diseases, USDA National Institute of Food and Agriculture. Nifa.usda.gov.

[3] Feakin, S.D. 1973. Pest control in groundnut. PANS Manual No.2. London, UK.

[4] Kranz, J., Schumutterer, H., Koch, W., eds., 1977. Diseases Pests and Weeds in Tropical Crops, Berlin and Hamburg, Germany; Verlag Paul Parley.

[5] Hill, D. 1975. Spodoptera litura(F.). In: Agricultural Insect Pests of the Tropics and their control. Cambridge University Press.

[6] Patnaik HP, 1998. Pheromone trap catches of Spodoptera litura F. and extent of damage on hybrid tomato in Orissa. Advances in IPM for horticultural crops. Proceeding of the First National Symposium on Pest Management in Horticultural Crop: environmental implications and thrusts, Bangalore, India, 15-17 October 1997.,68-72.

[7] Trivedi TP, 1988. Incidence of caterpillar on potato in Kolar, Karnataka. Current Research-University of Agricultural Sciences(Bangalore), 17(9):121.

[8] Bhattacharjee, N.S., Ghude, D.B. 1985. Effect of artificial and natural defoliation on the yield of soyabean. Indian Journal of Agricultural Sciences. 55(6): 427-429.

[9] Higuchi, H., Yamamoto, H., Suzuki, Y. 1994. Analysis of damage to soybeans infested by the common cutworm, Spodoptera litura Fabricius (lepidoptera:Noctuidae). II. Estimation of leaf area damaged by young larvae using spectral reflectivity. Japanese journal of Applied Entomology and Zoology. 38(4): 297-300.

[10] Roychoudhury, N., Shamila Kalia., Joshi, K.C. 1995. Pest status and larval feeding preference of Spodoptera litura on teak. Indian Forester, 121(6): 321-326.

[11] Salama, H.S., Shoukry, A. 1972. Flight range of the moth of the cotton leaf worm Spodoptera littoralis(Bois). Zeitschrift fur Angewandte Entomologie, 71(2): 181-184.

[12] Shimoda, M., and K. Honda. 2013. Insect reactions to light and its application to pest management. Applied Entomology and Zoology. 48: 413-421.

[13] CABI, EPPO, 1997. Mycosphaerella musicola.[ Distribution map] Distribution map of plant Diseases, December (Edition 8). Wallingford, UK: CAB International.

[14] Sosnowski, M.R., J.D.Fletcher., A.M.Daly., B.C.Rodoni and S.L.H, Viljanen_Rollinson. 2009. Techniques for the treatment, removal and disposal of host material during programmes for plant pathogen eradication. Plant Pathology. 58: 621-635.

[15] Patil,S.D., M.R.Patil and C.D.Badgujar. 2012. Varietal wealth of banana in Maharashtra: An Overview. Trends in Life Sciences. Vol.1, No.3, 50-53.

[16] Cintra, W., W.B.Moraes., R. Cecilio and F.A. Alves. 2008 Worldwide geographical distribution of Black Sigatoka for banana: Prediction based on climatic change model. Scientia Agricola. Vol.65.special issue: 40-53. 